\title{
Том \\ The coronavirus pandemic narratives in Italian digital media
}

\section{Javier Sierra-Sánchez, Natalia Abuín Vences and Jorge Milán Fitera}

Abstract

Keywords

DOI

Introduction
In this paper we discuss the SARS-CoV-2-related information coverage (beginning of the epidemic) in Italian digital media narratives. We surveyed the digital articles that reported the highest engagement level. The aim was to identify the most prominent variables (topics, players and news coverage area). Similarly, a discourse analysis was carried out by analyzing the tone used in relation to the variables mentioned. The results show that the most important topics were health, politics and the economy. Headlines appeared to be more likely to have a negative tone, although neutral headlines were the most common. The main feature in digital media headlines was civil society.

Health communication; Science and media

https://doi.org/10.22323/2.20020207

Submitted: 21st August 2020

Accepted: 5th January 2021

Published: 29th March 2021
Several studies showed that the advent of social media, the diversity of the channels [Hernández-Pérez and Rodríguez Mateos, 2016], the multiplicity of devices [Jenkins, 2006], the socialization of information consumption [Martínez-Costa, Sánchez-Blanco and Serrano-Puche, 2018], the velocity of real-time circulation of content [Guallar, 2011] as well as the emergence of new devices such as tablets, telephones and smartphones [Campos Freire, 2010] have led to the democratization of the access to information for the world's population. Culver and Jacobson [2012, p. 8] highlighted that technology has led to a new type of communication, which is easier, more accessible and immediate.

This easy access was observed during the most dramatic time of the COVID-19 epidemic in Italy. Molteni [2020] and Spini [2020] reported some data provided by broadband operators in Italy which concerns the days immediately after the Prime Ministerial Decree on the national lockdown issued on 8 March 2020. To begin with, on the first night (8-9 March) the Internet traffic increased by about $70 \%$. Subsequently, over the next seven days an average growth of $33 \%$ was reported versus the usual Internet traffic before the health emergency. 
As the Dire agency reported [2020], the fear generated by the pandemic immediately poured into the web. SemRush, a company specializing in daily surveys of the web and online reputation, decided to analyze the searches carried out over the past few months. The team noticed that, in the period from December 2019 to February 2020, the web searches for the "coronavirus" keyword amounted on average to approximately 9 million and a half each month.

Angelini [2020] explained that, in those dramatic hours, proper information given to the general public was appropriately considered fundamental as an instrument to manage the emergency. So, digital media plays a crucial role as it constantly provides real-time updates. Conversely, newspapers reported a worsening of their crisis, which was already certified by several studies conducted over the past few years [Labella, 2012; Amoedo, Vara-Miguel and Negredo, 2018].

With regard to web searches for news in the early days of the lockdown, based on the Audiweb and DataMediaHub surveys, Sorrentino [2020] reported that from 2 to 8 March 2020 the average number of accesses to the entire news segment went up by $50 \%$. A high number of users visited the main online Italian newspapers: La Repubblica reported an increase of 60\%, Il Corriere della Sera 72\%, La Stampa 109\% and Ansa 184\%. This situation was favored by the decision of news websites such as La Stampa and L'Avvenire to remove their paywall systems and give access to the vast majority of their articles free of charge to favor information during the emergency.

Additionally, the lockdown had several effects on the use of media in Italy. According to data by GroupM Research\&Insight [Brand News, 2020], the time spent watching TV increased on average of one hour and 15 minutes since the beginning of the epidemic; part of this time was devoted to entertainment, but also TV news programs reached a peak, reporting a $46 \%$ increase for national news and $69 \%$ for local news.

As pointed out by Hernández-Pérez and Rodríguez Mateos [2016], old media did not have a choice other than adapting in such a way to have their "products" and news be seen on mobile devices and digital platforms such as Facebook, Instagram, Twitter, YouTube, WhatsApp, Snapchat and many more, which were once alien to them, so that their content could spread. Indeed, even print media has increasingly invested in graphics, videos and interactive solutions that make its content more attractive so that it can still shine versus the new social media.

Accessing information through digital media
Our focus will be the analysis of the digital media headlines that were most popular at the peak of the epidemic emergency in Italy. It is necessary to provide a few interesting figures to understand what it means to access information through digital media.

A general framework was outlined in the Digital News Report 2020 by the Reuters Institute, which surveyed 40 countries, Italy included. Firstly, it should be pointed out that, in Italy, the general public's trust in news outlets has been particularly low for years. This is due to the biased nature of Italian journalism as well as the strong influence from politics and commercial interests on journalistic activities. The media outlets considered more trustworthy are in general those that are 
well-known for their independence from political parties, such as the state-run agency Ansa (trusted by $80 \%$ of users) and SkyTG24 (74\%). The news outlet that is considered less credible is the website Fanpage.it (45\%). Other interesting figures concerning trust levels are: Corriere della Sera (65\%), La Repubblica (61\%), La Stampa (59\%), Il Fatto Quotidiano (58\%) and Il Giornale (51\%).

The survey also found that smartphones are now the devices that are most used to read online news, with approximately two thirds $(63 \%)$ of the respondents using them to read the news every week. Personal computers only account for $38 \%$, and tablets for $17 \%$.

As a source of news, print media is used only by $22 \%$ of the sample, whereas TV and websites are tied: the former with $73 \%$ and the latter with $74 \%$ (including social media). In first place among the "top social media sites", there is Facebook, used by $56 \%$ of users looking for news, while in second and third place there are WhatsApp (29\%) and YouTube (24\%) respectively. Twitter only comes sixth as a platform to search for news, with a $9 \%$ share.

This data appears to reflect a crucial coexistence and complementarity [Dutta-Bergman, 2004] between traditional print media and digital media, in which social networks become facilitators of the former, improving its accessibility. There are several studies that demonstrated a positive correlation between the use of social networks and access to news, defined as incidental to them [Lee, 2009; Effing, van Hillegersberg and Huibers, 2011; Oeldorf-Hirsch and Sundar, 2015;

Boczkowski, Mitchelstein and Matassi, 2018]. Media outlets use Twitter and Facebook to promote their content and drive traffic to their websites. Whereas access to the social networks does not replace the media, it is also true that - owing to the Internet - there has been a change in the news content production and consumption process, as pointed out by Medina, Proust and Núñez-Mussa [2018].

Digital media operators discovered how essential it is to implement an effective engagement or commitment-led marketing strategy centered around the users as well as their motivations and abilities to interact with the messages. Martí and Muñoz [2008, p. 41] said that the media has to deal with the always new challenge of reaching their audience in a saturated and ever-changing market environment like the one generated by the digital revolution of information.

This eagerness that media outlets have to drive traffic to their sites - a key factor to generate revenues by selling advertising spaces - leads to clickbait or cyber-bait strategies. Certain media outlets base such strategies on sensationalist headlines, the purpose of which is to lead users to click on them, and therefore promote the spread of such material through the social networks. They take advantage of the naïve curiosity of readers who are led to click on the headlines. In order to do so, they provide only enough information to pique their interest, but only reveal the full facts when the readers access their content. It should be noted that the headline is the centerpiece of an article, because it is the first thing that people see. In order to draw attention, the most interesting part of the text is highlighted to spur users to continue reading the rest. In theory, the main function of a headline is to give readers the gist of an article, "condensing" its main information. However, it is not always so. Certain headlines do not provide a summary of the piece of news, and only focus on aspects that may often be irrelevant but more easily draw the reader's attention [Liang and $\mathrm{Wu}, 2018]$. 
In this regard, the relationship between emotion and virality should not be forgotten: messages that elicit emotions, whether positive or negative, often have a greater impact than neutral ones [Berger and Milkman, 2012].

All such data allows us to say that digital media and the users' interaction with the news content have given a new meaning to the uses and gratifications theory. This explains why in the digital domain users prefer certain content over other. In addition, it highlights something that nowadays is an unquestionable reality: the concept of an active audience, already postulated in the early days of this theory.

\section{Uses and gratifications theory applied to digital media}

The origin of the uses and gratifications theory (also abbreviated as UGT) dates back to the 50s with the beginning of empirical research on mass communication. Back then, one of the main objects of study was the effect that mass media had on the general public. Soon thereafter, research was conducted on the reasons that lead people to seek out specific media.

In 1973, Katz, Blumler and Gurevitch postulated UGT by assuming that the audience is like a challenge to information producers. According to them, gratifications for the audience would come from at least three different sources: media content, exposure to such content and social context. UGT explains the social and psychological origins of the needs that guide media exposure and selection to satisfy the individual needs of the audience [Katz, Blumler and Gurevitch, 1973]. According to this approach, individuals are active media users and usually act based on their goals. In fact, it is their motives that can explain media exposure, as they choose specific media to satisfy specific needs [Blumler, 1979; Katz, Haas and Gurevitch, 1973]. Rooted in this approach, the concept of needing specific media for orientation provides a psychological explanation of the reason why people look for information in the media: they need to become familiar with the environment through the media [Matthes, 2006; Weaver, 1980].

This well-established theory took on particular importance with the emergence of digital media, which totally changed the relationship with the audience. Members of the audience can now comment and share their own content, and this way their opinions can become viral in a matter of hours. This led the concept of active audience to reach a new dimension. Indeed, this concept was put forward by the pioneering UGT researchers to highlight the purposes and the attention in media consumption, in contrast with the common assumption - listed among the effects of traditional mass media - of a "passive audience" [Rubin, 2009]. With the advent of digital media, this has become an obvious reality [Sundar and Limperos, 2013]. According to the same authors, the Internet audience is so active that we refer to its members as users, in line with the essence of the UGT paradigm.

With regard to the active audience, in digital media we have to distinguish two types of audience: the social audience and the creative audience. We can define social audience as those people who use two screens or two devices at the same time [Deltell Escolar, 2014]. The concept of creative audience was originally coined by sociologist Manuel Castells in 2011 to refer to that share of the social audience that interacts and creates opinions. It is a new model of audience that has emerged with the Internet and the social media in particular. Viewers are no longer mere passive readers of audio-visual text, but creators of replies and transmedia text. 
Audience, dissemination and engagement
One of the great advantages of digital media versus old media lies in the fact that it allows you to enjoy information or entertainment content at any time, thanks to the mobile broadband and from anywhere, through connected devices. This is the reason why it seems fit to measure consumption in terms of dissemination and engagement, rather than in terms of audience. In this context, by dissemination we mean the number of individuals that see a certain item of content. Here, we exclusively refer to the fact that an item of content reaches a user, without any type of engagement.

When a piece of news is able to generate a creative audience, we refer to it as engagement and participation. According to the research on engagement processes, it has a nature that is intrinsically social, relational and interactive [Dessart, 2017]. The definition of the term also implies cognitive, emotional and behavioral aspects [Gambetti, Graffigna and Biraghi, 2012]. In addition to interactivity, Bowden [2009] added co-creation and multidimensionality. This brings about an audience that comments, interacts and generates opinions.

Therefore, engagement as an index that quantifies certain forms of interaction on social media [Hollebeek, Glynn and Brodie, 2014; Raimondo Anselmino, Sambrana and Cardoso, 2017] seems to be quite relevant in the analysis of the enjoyment and circulation of news. The industry of conventional media is aware of the need to renew the methods to measure the audience, in order to know how many people were actually reached by the content broadcast, a number that is currently very vague. Such new methods should focus more on the users than the media.

In order to understand the concept of engagement applied to the consumption of information content on digital media, we should go back to UGT and the concept of active audience, according to which users deliberately seek out specific media outlets for a specific reason [Mersey, Malthouse and Calder, 2010]. Already in 1987 Stone pointed out that people do not listen to the messages they are not interested in. They prefer content that offers elements they consider valuable, even if the value only amounts to a momentary pleasure.

Mersey, Malthouse and Calder [2010] defined engagement as the result of the cumulative experience of a reader with the digital medium involved. They also showed that there are two forms of engagement: personal and social-interactive. The former refers to personal perceptions, such as "this website makes me think about new things" or "this website often gives me something to talk about", which may also appear with traditional mass media. The latter is specific to digital media and provides experiential elements such as "this website allows me to socialize" and "I can contribute my opinion to the conversation on this website".

In this sense, we should also consider how news circulates in the digital environment and reflect on how its dissemination is influenced by the fact that an online audience can more easily access the content, both in terms of global and local news.

From a mass communication pattern, which ranges from one broadcaster (or a small group of broadcasters) to several scattered broadcasters that are mostly isolated from one another, we moved to a network pattern in which each citizen represents a node able to receive, share, retouch and build new information. 
According to Mitchelstein and Boczkowski [2018], we have access to such new information in a brief, interrupted and partial way: its consumption is ephemeral. The issue is to understand which type of content draws the attention of the digital audience, to understand which content becomes more widespread and generates more engagement during a crisis, like in the case of COVID-19.

On the basis of a longitudinal survey of the digital media headlines that became more popular and generated more engagement, the general goal of this study is to establish which type of approach digital media adopted with the SARS-CoV-2 pandemic.

The main goal of this work is to evaluate the digital media articles that were more popular and engaging during the COVID-19 crisis in order to learn about the subjects, information players and type of headlines concerning the health crisis.

In addition to this general goal, there are the following specific goals:

- Examine the digital media headlines that generated the highest amount of contacts/level of engagement to understand more precisely which subjects and purposes (tone) they feature.

- Study the player and the information area of digital media headlines, to discover the type that was more predominant during the pandemic.

- Carry out an analysis of the discourse of the headlines, in order to establish the various positionings.

- Define the reality projected by major pieces of news to establish the thematic taxonomy of each medium under investigation.

\section{Methodology}

To reach such goals, we defined a method for a longitudinal search (from 1 January to 27 April 2020) of the pieces of news appeared in the Italian digital information portals (.it). Therefore, the digital media/portals with a .org or .com domain were excluded from the search. We developed a quantitative and qualitative analysis method on the basis of the information obtained. Then we used comprehensive big data tools offered by the web content analysis application Buzzsumo, based on a search and web analysis algorithm. In order to do that, we applied geographical (Italy), time (January-April) and semantic (COVID 19 and Coronavirus) filters to extract the information to be investigated.

The parameters underlying the automatic selection of the content were dissemination and engagement. In other words, we selected the digital content that was most spread during the selected time interval, i.e. the content that was seen by the largest number of people and the content that generated the highest level of engagement, i.e. the content with which users had interacted by sharing it or adding a comment to it.

Thus, we obtained detailed data (daily, weekly and monthly) to understand the media coverage of this unprecedented global pandemic. We also wanted to learn 
about the tone and the purpose of the headlines that were most spread and with the highest level of engagement among the population. In this sense, we decided to categorize front-page highlights based on the predominance of positive, negative or ambivalent sentences concerning the pandemic [Bardin, 1986; López-Aranguren, 1989; Piñuel Raigada and Gaitán Moya, 1995].

The potential finds concerning news on the health crisis were processed according to content analysis methods [Berelson, 1952; López, 1963; Krippendorff, 1990]. Such methodology provided a system of categories to classify the information contained in the news on the basis of a pre-established criterion. Each piece of news was classified according to the following main variables:

1. Website that originated the piece of news: papers/information portal with a it domain or headquarters in Italy.

2. The social networks through which the piece of news was circulated, in order to understand which sites report higher dissemination/engagement levels: Facebook, Twitter, Pinterest and Reddit.

3. Subject: the health crisis on the basis of the two key words surveyed (COVID-19 and Coronavirus).

4. Sample: the ten pieces of news from each digital media site that reported the highest dissemination/engagement level for each term surveyed. News related to the term Coronavirus (100) and the term COVID-19 (100).

5. Medium

6. Main theme: politics, economy, employment, international affairs, health, education, European Union, environment, energy, sports, industry, social policies.

7. Type of player featured in the piece of news: institutional/official, political, economic, alternative, civil society, media system, cultural, other.

8. Information area: Italy, global/world reference, United States, European Union, Russia, Asia, Latin America, Middle East and Maghreb, Sub-Saharan Africa.

9. Tone of the headline: positive, negative or neutral.

10. Media outlets surveyed: ansa.it, blogsicilia.it, corriere.it, fanpage.it, greenme.it, huffingtonpost.it, ilfattoquotidiano.it, ilgiornale.it, ilmattino.it, ilmessaggero.it, lastampa.it, malpensa24.it, mediaset.it, napolitoday.it, repubblica.it, secoloditalia.it, tpi.it

We basically opted for the use of a quantitative, descriptive and longitudinal method: we used the qualitative variable only for the tone analysis of the headlines of the pieces of news that were most widespread at the global level. The qualitative analysis was carried out using the Atlas.ti v. 8.4.4 software application, while SPSS v. 25 was used for the statistical analysis. 
Results: description and analysis
Table 1 refers to the topic (subject or theme) the headlines are about. It shows that the headlines mainly focus on the health aspects of the crisis $(74 \%)$, followed (from a distance) by the economic concerns about the effects of the pandemic $(4.5 \%)$ and the political implications (3\%). A further $2.5 \%$ share dealt with assistance or social policies. It should be remembered that these headlines appeared in the first four months of the public health emergency, when the interest of users was focused on the data relating to the pandemic evolution, so this category of headlines was expected to be the one reporting the highest dissemination/engagement level, followed by economic and political issues which acquired increasingly more relevance as the emergency subsided. Such data reflects the need people had of orientation, as postulated by UGT: specially during lockdown, one of the forms they had to interface with the environment was the access to news.

Table 1. Main subjects (topics) of the headlines.

\begin{tabular}{|l|c|c|}
\hline & Occurrences (no.) & Share (\%) \\
\hline Environment & 2 & 1.0 \\
\hline Social services (social policies) & 5 & 2.5 \\
\hline Corruption & 1 & 0.5 \\
\hline Culture & 2 & 1.0 \\
\hline Economy & 9 & 4.5 \\
\hline Immigration & 3 & 1.5 \\
\hline Industry and manufacturing & 2 & 1.0 \\
\hline International affairs & 5 & 2.5 \\
\hline The judiciary & 1 & 0.5 \\
\hline Employment & 3 & 1.5 \\
\hline Territorial organization of the State & 3 & 1.5 \\
\hline Politics & 6 & 3.0 \\
\hline Religion & 3 & 1.5 \\
\hline Health & 148 & 74.0 \\
\hline Sports & 2 & 1.0 \\
\hline Terrorism & 1 & 0.5 \\
\hline European Union & 3 & 1.5 \\
\hline Other & 1 & 0.5 \\
\hline Total & 200 & 100.0 \\
\hline
\end{tabular}

In addition, we were interested in surveying the tone of the headlines, so we categorized front-page headlines based on the predominance of positive, negative or neutral sentences with regard to the Covid-19 pandemic. Table 2 is about the tone of the headlines and shows that the neutral tone accounts for a higher share than the positive or negative tones.

Table 2. Tone (purpose/intention) of the headlines.

\begin{tabular}{|l|c|c|}
\hline & Occurrences (no.) & Share (\%) \\
\hline Negative & 67 & 33.5 \\
\hline Neutral & 88 & 44.0 \\
\hline Positive & 45 & 22.5 \\
\hline Total & 200 & 100.0 \\
\hline
\end{tabular}


As can be seen, the most popular headlines have a neutral tone. Well far behind, headlines with a negative tone come in second place. The explanation of this lies in the relationship between emotion and virality [Berger and Milkman, 2012].

Following are the results relating to the protagonist (player) of the information variable of the headlines. This makes it possible to see in detail who elicited the greatest interest.

Table 3. Information players (protagonists) of the headlines.

\begin{tabular}{|l|c|c|}
\hline & Occurrences (no.) & Share (\%) \\
\hline Athletes/Sportspeople & 1 & 0.5 \\
\hline Police and armed forces & 5 & 2.5 \\
\hline Cultural & 7 & 3.5 \\
\hline Economic & 7 & 3.5 \\
\hline Institutional/Official & 42 & 21.0 \\
\hline Media & 5 & 2.5 \\
\hline Political & 13 & 6.5 \\
\hline Religious & 3 & 1.5 \\
\hline Healthcare & 50 & 25.0 \\
\hline Civil society & 51 & 25.5 \\
\hline Other & 16 & 8.0 \\
\hline Total & 200 & 100.0 \\
\hline
\end{tabular}

It is clear that digital media headlines during the healthcare emergency put the stress on civil society, treating it as the main player of topical issues $(25.5 \%)$, closely followed by health professionals (physicians, nurses, infectious disease doctors, etc.) at $25 \%$. Government and official institutions came in third place $(21 \%)$.

We can also notice that the fourth slot is occupied by "Other". Table 4 shows which other players came to prominence in the media during the first phase of this health emergency.

Table 4. Other information players.

\begin{tabular}{|l|c|c|}
\hline & Occurrences (no.) & Share (\%) \\
\hline & 184 & 92.0 \\
\hline Funeral homes & 1 & 0.5 \\
\hline Pets & 4 & 2.0 \\
\hline Gas stations & 1 & 0.5 \\
\hline Illegal immigrants & 1 & 0.5 \\
\hline Entrepreneurs & 4 & 2.0 \\
\hline Non-profit organizations & 3 & 1.5 \\
\hline Researchers & 1 & 0.5 \\
\hline Gypsies & 1 & 0.5 \\
\hline Total & 200 & 100.0 \\
\hline
\end{tabular}

It can be seen that pets sometimes $(2 \%)$ were mentioned in the digital medial headlines that became most widespread, and this is connected with the risk that they could carry the virus. At the same level we find entrepreneurs ( $2 \%)$ for two 
fundamental reasons: donations and the economic measures adopted during the state of alert. Finally, non-profit organizations can be added to the list $(1.5 \%)$, especially in connection with the former reason, as they demonstrated their solidarity social function.

Table 5 concerns the information space of the headlines. Italian online media approached the subject especially at the national level (67.5\%), while $12.5 \%$ of the headlines mentioned the European Union and 6.5\% the United States. Quite curiously, Asia - which was at the origin of the pandemic - only accounts for a small share of the most popular pieces of news (only $6 \%$ of the headlines).

Table 5. Information space (coverage area) of the pieces of news.

\begin{tabular}{|l|c|c|}
\hline & Occurrences (no.) & Share (\%) \\
\hline Latin America & 3 & 1.5 \\
\hline Asia & 12 & 6.0 \\
\hline Italy (national, regional, local) & 135 & 67.5 \\
\hline Middle East and Maghreb & 4 & 2.0 \\
\hline Global/World & 7 & 3.5 \\
\hline Russia & 1 & 0.5 \\
\hline United States & 13 & 6.5 \\
\hline European Union & 25 & 12.5 \\
\hline Total & 200 & 100.0 \\
\hline
\end{tabular}

In Table 6 we examined the tone used in relation to these three variables: digital media, the subject (topic/theme) of the headline and the information player. We can see how the tone influenced each of such variables from a descriptive point of view.

In view of the findings, we can say that corriere.it and ilgiornale.it are the digital media outlets that published the most negative headlines. On the contrary, ilmattino.it mostly published headlines with a positive tone. Certain media outlets, especially ansa.it and ilmessaggero.it, created a perfect balance between negative and positive headlines. In the case of ilmessaggero.it, the predominance of neutral headlines is quite remarkable. This is a trend detected also in the headlines of lastampa.it and repubblica.it, although in both cases a slight tendency towards negative headlines was reported.

In Table 7 we surveyed the tone (purpose/intention) of the headlines versus the theme (subject/topic). Quite interestingly, health was the subject of the majority of the headlines (148 overall). In that group, 52 had a negative tone, 61 a neutral tone and 35 a positive tone. Therefore, a certain degree of pessimism was detected in the main subject approached by the digital media in the framework of the coronavirus emergency. In the same way, we noticed that the aspects concerning social policies and territorial organization of the State were the subjects proportionately most connected with the most negative headlines. On the other hand, the subjects that were approached with positive headlines were health, economy and politics, in a descending order. Such three subjects coincide with the sectors that were hit the hardest by the crisis, so they clearly were focal points for the readers' interest. The fact that the media often approach them with a positive or negative tone instead of 
Table 6. Cross-reference table of the tone and digital medium variables.

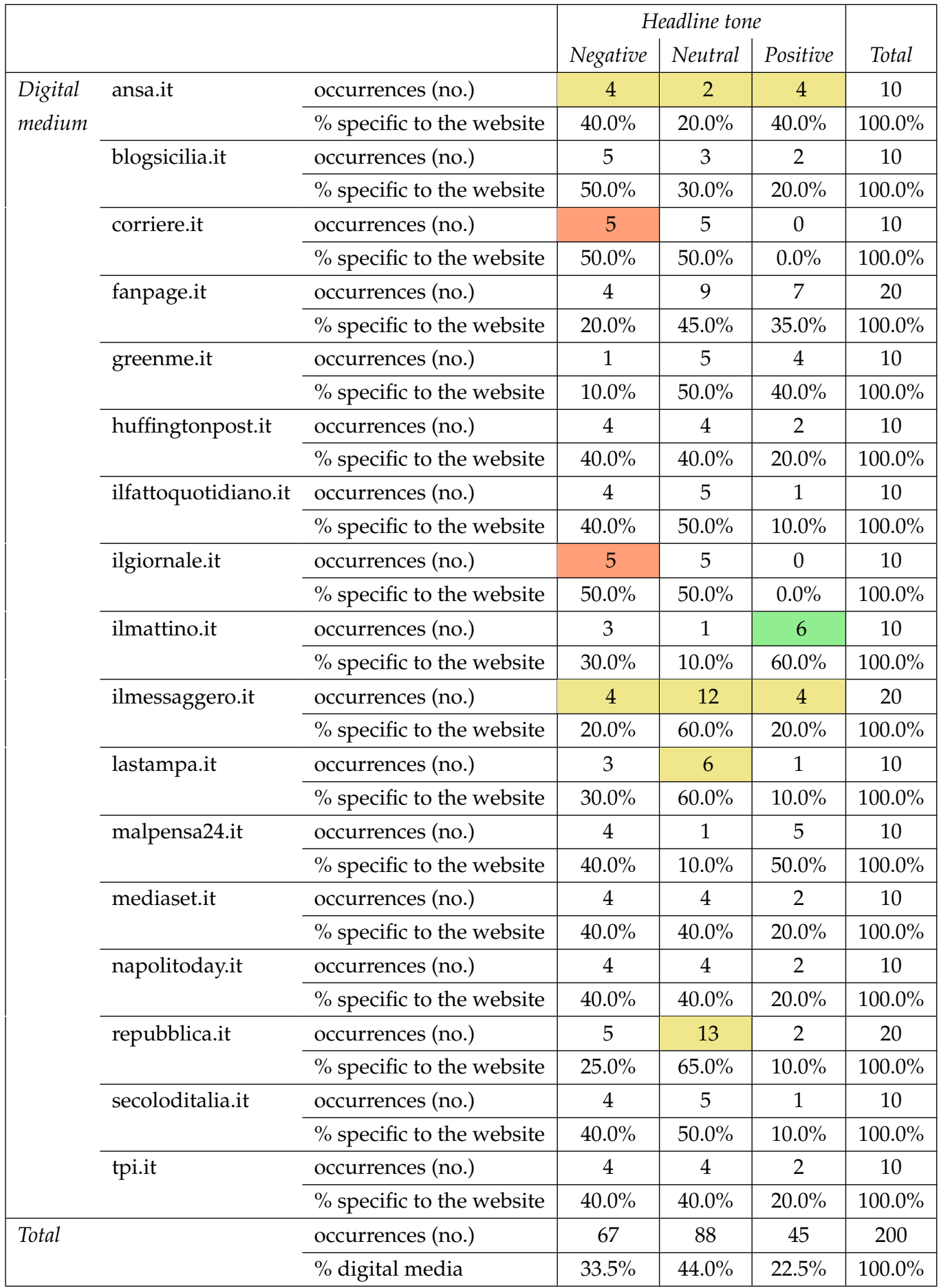

a neutral one strengthens their dissemination/engagement level, eliciting emotions that push users to read and share the articles, often along with a personal comment.

Finally, Table 8 surveyed the tone used in the headlines in relation to the other information players of this health emergency.

More in detail, the negative headlines relating to civil society are about the deceased, the failure to comply with lockdown measures and the loss of dear ones. 
Table 7. Cross-reference table of the headline tone and subject variables.

\begin{tabular}{|c|c|c|c|c|c|c|}
\hline & & & \multicolumn{3}{|c|}{ Headline tone } & \multirow[b]{2}{*}{ Total } \\
\hline & & & Negative & Neutral & Positive & \\
\hline \multirow{36}{*}{$\begin{array}{l}\text { Headline } \\
\text { subject }\end{array}$} & \multirow{2}{*}{ Environment } & occurrences (no.) & 0 & 2 & 0 & 2 \\
\hline & & $\%$ relating to the headline subject & $0.0 \%$ & $100.0 \%$ & $0.0 \%$ & $100.0 \%$ \\
\hline & \multirow{2}{*}{$\begin{array}{l}\text { Social services } \\
\text { (social policies) }\end{array}$} & occurrences (no.) & 3 & 1 & 1 & 5 \\
\hline & & $\%$ relating to the headline subject & $60.0 \%$ & $20.0 \%$ & $20.0 \%$ & $100.0 \%$ \\
\hline & \multirow[t]{2}{*}{ Corruption } & occurrences (no.) & 0 & 1 & 0 & 1 \\
\hline & & $\%$ relating to the headline subject & $0.0 \%$ & $100.0 \%$ & $0.0 \%$ & $100.0 \%$ \\
\hline & \multirow[t]{2}{*}{ Culture } & occurrences (no.) & 1 & 1 & 0 & 2 \\
\hline & & $\%$ relating to the headline subject & $50.0 \%$ & $50.0 \%$ & $0.0 \%$ & $100.0 \%$ \\
\hline & \multirow[t]{2}{*}{ Economy } & occurrences (no.) & 2 & 3 & 4 & 9 \\
\hline & & $\%$ relating to the headline subject & $22.2 \%$ & $33.3 \%$ & $44.4 \%$ & $100.0 \%$ \\
\hline & \multirow[t]{2}{*}{ Immigration } & occurrences (no.) & 2 & 1 & 0 & 3 \\
\hline & & $\%$ relating to the headline subject & $66.7 \%$ & $33.3 \%$ & $0.0 \%$ & $100.0 \%$ \\
\hline & \multirow{2}{*}{$\begin{array}{l}\text { Industry and } \\
\text { manufacturing }\end{array}$} & occurrences (no.) & 0 & 1 & 1 & 2 \\
\hline & & $\%$ relating to the headline subject & $0.0 \%$ & $50.0 \%$ & $50.0 \%$ & $100.0 \%$ \\
\hline & \multirow{2}{*}{$\begin{array}{l}\text { International } \\
\text { affairs }\end{array}$} & occurrences (no.) & 1 & 4 & 0 & 5 \\
\hline & & $\%$ relating to the headline subject & $20.0 \%$ & $80.0 \%$ & $0.0 \%$ & $100.0 \%$ \\
\hline & \multirow[t]{2}{*}{ The judiciary } & occurrences (no.) & 0 & 1 & 0 & 1 \\
\hline & & $\%$ relating to the headline subject & $0.0 \%$ & $100.0 \%$ & $0.0 \%$ & $100.0 \%$ \\
\hline & \multirow[t]{2}{*}{ Employment } & occurrences (no.) & 0 & 3 & 0 & 3 \\
\hline & & $\%$ relating to the headline subject & $0.0 \%$ & $100.0 \%$ & $0.0 \%$ & $100.0 \%$ \\
\hline & \multirow{2}{*}{$\begin{array}{l}\text { Territorial organization } \\
\text { of the State }\end{array}$} & occurrences (no.) & 3 & 0 & 0 & 3 \\
\hline & & $\%$ relating to the headline subject & $100.0 \%$ & $0.0 \%$ & $0.0 \%$ & $100.0 \%$ \\
\hline & \multirow[t]{2}{*}{ Politics } & occurrences (no.) & 1 & 2 & 3 & 6 \\
\hline & & $\%$ relating to the headline subject & $16.7 \%$ & $33.3 \%$ & $50.0 \%$ & $100.0 \%$ \\
\hline & \multirow[t]{2}{*}{ Religion } & occurrences (no.) & 0 & 3 & 0 & 3 \\
\hline & & $\%$ relating to the headline subject & $0.0 \%$ & $100.0 \%$ & $0.0 \%$ & $100.0 \%$ \\
\hline & \multirow[t]{2}{*}{ Health } & occurrences (no.) & 52 & 61 & 35 & 148 \\
\hline & & $\%$ relating to the headline subject & $35.1 \%$ & $41.2 \%$ & $23.6 \%$ & $100.0 \%$ \\
\hline & \multirow[t]{2}{*}{ Sports } & occurrences (no.) & 0 & 1 & 1 & 2 \\
\hline & & $\%$ relating to the headline subject & $0.0 \%$ & $50.0 \%$ & $50.0 \%$ & $100.0 \%$ \\
\hline & \multirow[t]{2}{*}{ Terrorism } & occurrences (no.) & 1 & 0 & 0 & 1 \\
\hline & & $\%$ relating to the headline subject & $100.0 \%$ & $0.0 \%$ & $0.0 \%$ & $100.0 \%$ \\
\hline & \multirow[t]{2}{*}{ Other } & occurrences (no.) & 0 & 1 & 0 & 1 \\
\hline & & $\%$ relating to the headline subject & $0.0 \%$ & $100.0 \%$ & $0.0 \%$ & $100.0 \%$ \\
\hline & \multirow[t]{2}{*}{ European Union } & occurrences (no.) & 1 & 2 & 0 & 3 \\
\hline & & $\%$ relating to the headline subject & $33.3 \%$ & $66.7 \%$ & $0.0 \%$ & $100.0 \%$ \\
\hline \multirow{2}{*}{\multicolumn{2}{|c|}{ Total }} & occurrences (no.) & 67 & 88 & 45 & 200 \\
\hline & & \% headline subjects & $33.5 \%$ & $44.0 \%$ & $22.5 \%$ & $100.0 \%$ \\
\hline
\end{tabular}

With reference to the institutional/official aspects, they refer to the less-than-optimal management of the health crisis by the government. The same is true for police forces: what is highlighted is the excessive strictness of the checks at the beginning of lockdown. In relation to healthcare assistance, the negative headlines mention the infections and deaths - sometimes suicides — of first-line 
Table 8. Cross-reference table of the information player and headline tone variables.

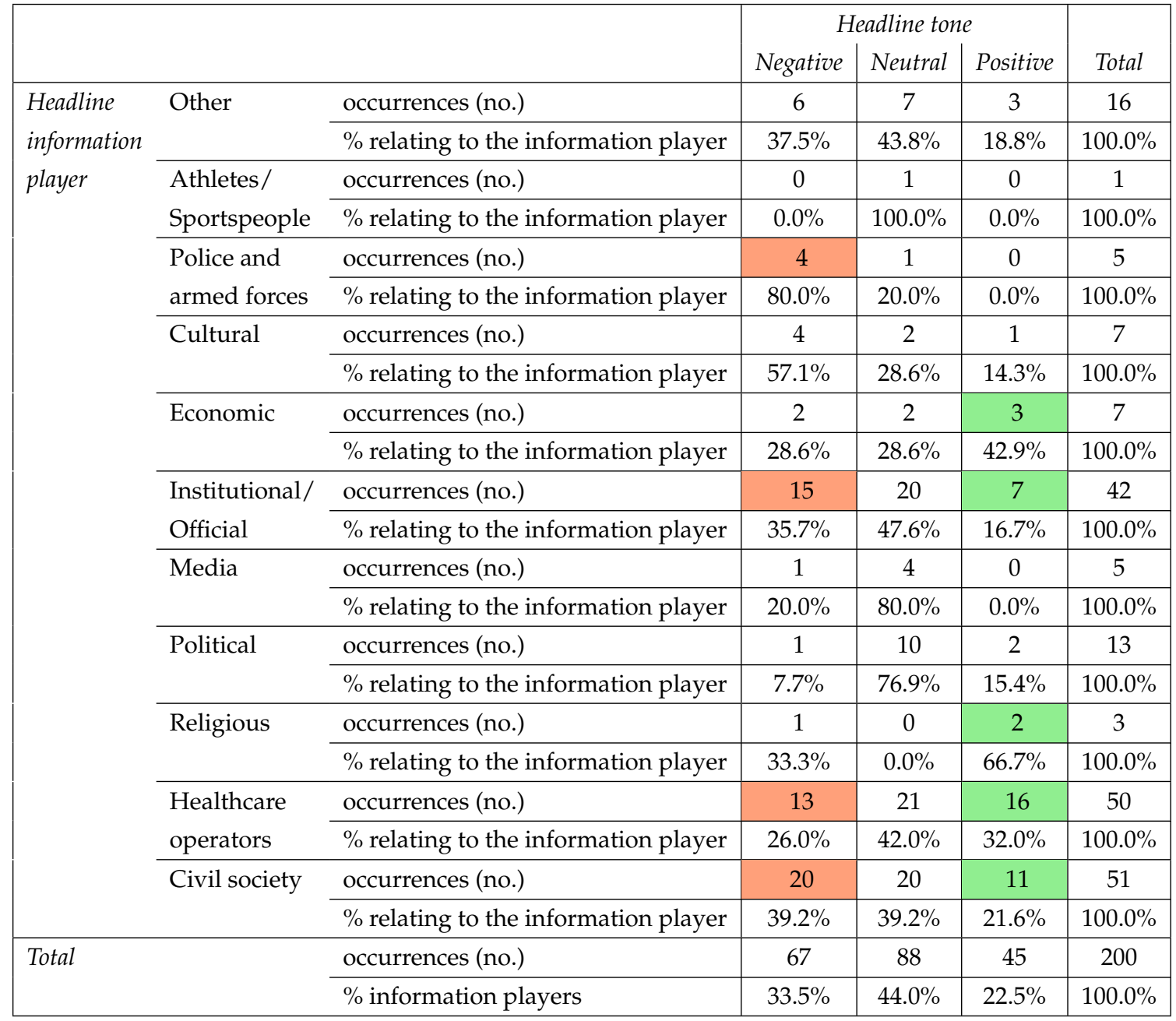

healthcare operators (physicians, nurses, etc.) and the unsuitableness of the personal protective equipment supplied to them or the lack thereof.

With respect to the positive tone, in first place we find the commitment and the dedication of the healthcare staff and the scientists to research on a vaccine and to effective treatments. With reference to civil society, the stress was put on the solidarity initiatives (donations in terms of funds and healthcare material) for the most vulnerable people. Other elements are highlighted such as the first patients recovered from SARS-CoV-2 and discharged from the hospitals and the early news about a reduction in the infections and deaths among the population. With regard to the most relevant positive aspects in the institutional/official category, the media covered the policies relating to the subsidies allocated to mitigate the impact of coronavirus. In relation to the positive aspects that concern the economic players (entrepreneurs, various companies), they are in line with the social and economic support measures by companies as well as state-run institutions, such as donation of funds and healthcare material to hospitals by companies. Finally, it is interesting to point out that there was a positive view of solidarity initiatives by religious operators, including an initiative by Pope Francis in support of sick people. 
A few conclusions can be drawn on the basis of the data obtained from the survey of SARS-CoV-2 news:

1. The headlines relating to the SARS-CoV-2 pandemic that recorded the highest dissemination/engagement levels were mainly about health, politics (management of the crisis and measures adopted while in a state of emergency, including the division of the national territory into different areas based on the risk, social policies) as well as economic issues (subsidies to reduce the devastating consequences of the health emergency). This can be explained by the need for orientation postulated by UGT.

2. With regard to the tone used in the headlines, a slight tendency towards negative headlines was reported. However, neutral headlines were the majority within the total number of headlines included in the media sample. We can say that the media outlets that most commonly used a negative tone were ilcorriere.it and il giornale.it, while a positive tone was used only by ilmattino.it. Nevertheless, a certain symmetry and balance usually prevailed (same share of negative and positive headlines), especially in news outlets such as ansa.it and ilmessaggero.it. The polarization of positive and negative headlines finds an explanation in the relationship between emotional charge and virality, regardless of the fact that the latter is positive or negative: this type of news is more likely to be clicked by users.

3. Civil society was the information player that elicited the greatest interest of digital media as a protagonist of the pandemic, with pieces of news outnumbering (by far) those about the government and the healthcare operators (although by a smaller margin). It is worthwhile to stress the important secondary role that businessmen and artists played in the headlines (some expressing their complete solidarity and full commitment to society). In a certain sense, all this is in line with the first conclusion, where we saw that headlines were mostly about health, politics and economy: the main players - in the following order: civil society, healthcare operators, politicians, entrepreneurs and artists - have a direct relation with the three main themes, health, politics and economy.

4. Digital media has focused on the crisis especially at the national (regional and local) level although media outlets also reported, in a very limited way, what was happening in China, the United States and certain European countries (the U.K., France and Germany in particular).

5. It is interesting to notice that the subjects with the most negative as well as positive headlines were health, economy and politics. It should be remembered that these are the three main areas of interests in the media.

6. In relation to the tone used about the main players, we observed that civil society, healthcare operators and the government fundamentally were the subjects of the majority of positive and negative headlines. While in the second instance positive headlines were slightly higher than the negative ones, in the first and third instances (civil society and government), the negative headlines amounted to twice as much as the positive ones. 
Agenzia DiRE (5th March 2020). 'Il coronavirus impazza sul web, 9 milioni e mezzo di ricerche al mese'. Dire.it. URL: https://www .dire.it/05-03-2020/429912-coronavirus-web/.

Amoedo, A., Vara-Miguel, A. and Negredo, S. (2018). Digital News Report 2018: una audiencia diversa y preocupada por la desinformación. Pamplona, Spain: Digital UNAV - Center for Internet Studies and Digital Life. URL: http://www . digitalnewsreport.es/category/2018/.

Angelini, F. (25th February 2020). 'La comunicazione social ai tempi del coronavirus. Ci si informa su FB e Youtube, si commenta su Twitter'. Prima Comunicazione. URL: https://bit.1y/3g9oQcL.

Bardin, L. (1986). El análisis de contenido. Madrid, Spain: Akal.

Berelson, B. (1952). Content analysis in communication research. New York, U.S.A.: Hafner.

Berger, J. and Milkman, K. L. (2012). 'What makes online content viral?' Journal of Marketing Research 49 (2), pp. 192-205. https://doi.org/10.1509/jmr.10.0353.

Blumler, J. G. (1979). 'The role of theory in uses and gratifications studies'. Communication Research 6 (1), pp. 9-36. https://doi.org/10.1177/009365027900600102.

Boczkowski, P. J., Mitchelstein, E. and Matassi, M. (2018). “"News comes across when I' $m$ in a moment of leisure": understanding the practices of incidental news consumption on social media'. New Media $\mathcal{E}$ Society 20 (10), pp. 3523-3539. https://doi.org/10.1177/1461444817750396.

Bowden, J. L.-H. (2009). 'The process of customer engagement: a conceptual framework'. Journal of Marketing Theory and Practice 17 (1), pp. 63-74. https://doi.org/10.2753/MTP1069-6679170105.

Brand News (7th April 2020). 'L'analisi di GroupM - Coronavirus / 10: Ascolti TV sempre in aumento, cresce l'uso quotidiano delle app dedicate alle videochat'. Brand-news.it. URL: https://bit.1y/3g8NREL.

Campos Freire, F. (2010). 'Los nuevos modelos de gestión de las empresas mediáticas'. Estudios sobre el Mensaje Periodístico 16, pp. 13-30. URL: https: //rev istas .ucm.es/index.php/ESMP/article/view/ESMP1010110013A.

Castells, M. (2011). Comunicación y poder. Madrid, Spain: Alianza Editorial.

Culver, S. and Jacobson, T. (2012). 'Alfabetización mediática como método para fomentar la participación cívica'. Comunicar: Revista Científica Iberoamericana de Comunicación y Educación 39, pp. 73-80. https://doi.org/10.3916/C39-2012-02-07.

Deltell Escolar, L. (2014). 'Audiencia social versus audiencia creativa: caso de estudio Twitter'. Estudios sobre el Mensaje Periodístico 20 (1), pp. 33-47. https://doi.org/10.5209/rev_ESMP.2014.v20.n1.45217.

Dessart, L. (2017). 'Social media engagement: a model of antecedents and relational outcomes'. Journal of Marketing Management 33 (5-6), pp. 375-399. https://doi.org/10.1080/0267257X.2017.1302975.

Dutta-Bergman, M. J. (2004). 'Complementarity in consumption of news types across traditional and new media'. Journal of Broadcasting $\mathcal{E}$ Electronic Media 48 (1), pp. 41-60. https://doi.org/10.1207/s15506878jobem4801_3.

Effing, R., van Hillegersberg, J. and Huibers, T. (2011). 'Social media and political participation: are Facebook, Twitter and YouTube democratizing our political systems?' In: ePart 2011: International Conference on Electronic Participation. Ed. by E. Tambouris, A. Macintosh and H. de Bruijn. Berlin and Heidelberg, Germany: Springer, pp. 25-35. https://doi.org/10.1007/978-3-642-23333-3_3. 
Gambetti, R. C., Graffigna, G. and Biraghi, S. (2012). 'The grounded theory approach to consumer-brand engagement: the practitioner's standpoint'. International Journal of Market Research 54 (5), pp. 659-687. https: //doi.org/10.2501/IJMR-54-5-659-687.

Guallar, J. (2011). ‘Prensa digital en 2010'. Anuario ThinkEPI 5, pp. 101-105.

Hernández-Pérez, T. and Rodríguez Mateos, D. (2016). ‘Medición integral de las audiencias: sobre los cambios en el consumo de información y la necesidad de nuevas métricas en medios digitales'. Hipertext.net 14.

URL: http://raco.cat/index.php/Hipertext/article/view/310968/405628.

Hollebeek, L. D., Glynn, M. S. and Brodie, R. J. (2014). 'Consumer brand engagement in social media: conceptualization, scale development and validation'. Journal of Interactive Marketing 28 (2), pp. 149-165. https://doi.org/10.1016/j.intmar.2013.12.002.

Jenkins, H. (2006). Fans, bloggers, and gamers: exploring participatory culture. New York, U.S.A.: NYU Press.

Katz, E., Blumler, J. G. and Gurevitch, M. (1973). 'Uses and gratifications research'. The Public Opinion Quarterly 37 (4), pp. 509-523. URL: http://www. jstor.org/stable/2747854.

Katz, E., Haas, H. and Gurevitch, M. (1973). 'On the use of the mass media for important things'. American Sociological Review 38 (2), pp. 164-181. https://doi.org/10.2307/2094393.

Krippendorff, K. (1990). Metodología de análisis de contenido: teoría y práctica. Barcelona, Spain: Paidós.

Labella, L. I. (2012). 'Saturación informativa: la multiplicación de la oferta a través de Internet no aumenta el consumo de noticias'. Razón y Palabra 81.

Lee, J. K. (2009). 'Incidental exposure to news: limiting fragmentation in the new media environment'. Ph.D. Dissertation. Austin, U.S.A.: The University of Texas at Austin. URL: http://hdl . handle.net/2152/6686.

Liang, C.-C. and Wu, R.-Y. (2018). 'A pilot study of the impact of emotions to exaggerated news title'. In: International Conference on Internet Studies (Nets 2018) (Takamatsu, Japan, 2nd-4th April 2018). URL: https://bit. 1y/2MxHxcY.

López-Aranguren, E. (1989). 'El análisis de contenido'. In: El análisis de la realidad social. Métodos y técnicas de investigación. Ed. by M. García Ferrando, J. Ibáñez and F. Alvira. Madrid, Spain: Alianza.

López, E. M. (1963). 'El análisis de contenido'. Revista de Estudios Políticos 132, pp. $45-64$.

Martí, J. and Muñoz, P. (2008). Engagement marketing. Una nueva publicidad para un marketing de compromiso. Madrid, Spain: Pearson Educación.

Martínez-Costa, M. P., Sánchez-Blanco, C. and Serrano-Puche, J. (2018). ‘El consumo de noticias online en España: temáticas, formatos e itinerarios de acceso'. In: Mediamorfosis. Radiografía de la innovación en el periodismo. Ed. by J. L. González-Esteban and J. A. García-Avilés. Madrid, Spain: SEP Universidad Miguel Hernández de Elche, pp. 35-59.

Matthes, J. (2006). 'The need for orientation towards news media: revising and validating a classic concept'. International Journal of Public Opinion Research 18 (4), pp. 422-444. https://doi.org/10.1093/ijpor/edh118.

Medina, F. J. F., Proust, V. and Núñez-Mussa, E. (2018). 'Consumo incidental de noticias en un contexto de redes sociales y múltiples pantallas'. Revista Ibérica de Sistemas e Tecnologias de Informação E16, pp. 308-320. 
Mersey, R. D., Malthouse, E. C. and Calder, B. J. (2010). ‘Engagement with online media'. Journal of Media Business Studies 7 (2), pp. 39-56. https://doi.org/10.1080/16522354.2010.11073506.

Mitchelstein, E. and Boczkowski, P. J. (2018). 'Juventud, estatus y conexiones. Explicación del consumo incidental de noticias en redes sociales'. Revista Mexicana de Opinión Pública 24, pp. 131-145. https://doi.org/10.22201/fcpys.24484911e.2018.24.61647.

Molteni, E. (6th May 2020). 'Covid-19, Internet è diventato un servizio essenziale'. Fortune Italia. URL: https: //bit.1y/3g9EsNc.

Oeldorf-Hirsch, A. and Sundar, S. S. (2015). 'Posting, commenting, and tagging: effects of sharing news stories on Facebook'. Computers in Human Behavior 44, pp. 240-249. https://doi.org/10.1016/j.chb.2014.11.024.

Piñuel Raigada, J. L. and Gaitán Moya, J. A. (1995). Metodología general. Conocimiento científico e investigación en la comunicación social. Madrid, Spain: Editorial Síntesis.

Raimondo Anselmino, N., Sambrana, A. M. and Cardoso, A. L. (2017). 'Medios tradicionales y redes sociales en Internet: un análisis de los posteos compartidos por los diarios argentinos Clarín y La Nación en Facebook (2010-2015)'.

Astrolabio 19, pp. 32-68. URL: https://revistas. unc.edu.ar/index.php/astro labio/article/view/17787.

Rubin, A. M. (2009). 'The uses-and-gratifications perspective on media effects'. In: Media effects: advances in theory and research. Ed. by J. Bryant and M. B. Oliver. New York, U.S.A.: Routledge.

Sorrentino, F. (13th March 2020). 'Coronavirus, aumenta il consumo di notizie sui media'. Futura News. URL: https: //futura.news/coronavirus-aumenta-il-co nsumo-di-notizie-online/.

Spini, F. (22nd May 2020). 'Internet, dopo il boom del lockdown non si sgonfia il traffico della rete'. La Stampa. URL: https://bit. ly/2BG JphI.

Stone, G. L. (1987). Examining newspapers: what research reveals about America's newspapers. Newbury Park, CA, U.S.A.: SAGE Publications.

Sundar, S. S. and Limperos, A. M. (2013). 'Uses and grats 2.0: new gratifications for new media'. Journal of Broadcasting E Electronic Media 57 (4), pp. 504-525. https://doi.org/10.1080/08838151.2013.845827.

Weaver, D. H. (1980). 'Audience need for orientation and media effects'. Communication Research 7 (3), pp. 361-373. https://doi.org/10.1177/009365028000700305.

\section{Authors}

Prof. Javier Sierra-Sánchez.

Affiliation: Complutense University of Madrid (Spain). Ph.D. in Information Science at the Complutense University of Madrid (UCM), graduated in Audio-Visual Communication and Journalism from the same university. Adjunct professor at UCM. Department of Applied Communication Science.

H-index: 11

Orcid ID: 0000-0001-8572-7564

Google Scholar: https: / scholar.google.es / citations?user=oGqa6PgAAAAJ

ResearchGate: https://www.researchgate.net/profile/Javier_Sierra5

Scopus ID: https:/ / www.scopus.com/authid/detail.uri?authorId=55579423600

Academia.edu: https://ucm.academia.edu/JavierSierraSánchez

E-mail: javier_sierra@ucm.es. 
Prof.ssa Natalia Abuín Vences.

Affiliation: Complutense University of Madrid (Spain). Ph.D. in Audio-Visual Communication and Advertising at the Complutense University of Madrid (UCM). Lecturer in Organizational Culture at the Applied Communication Science, UCM. H-index: 11

ORCID ID: 0000-0002-4153-9390

Google Scholar: https:/ / scholar.google.com/citations?user=qBhjgBEAAAAJ

Web personal: https://nataliaabuin.wordpress.com

E-mail: nabuinve@ucm.es.

Prof. Jorge Milán Fitera.

Affiliation: The Pontifical University of the Holy Cross (Rome). Extraordinary Professor in Audio-Visual Communication at the Pontifical University of the Holy Cross. He graduated in Information Science (Journalism) from the Complutense University of Madrid. Ph.D. in Public Communication Research at the University of Navarra (Spain).

ORCID ID: 0000-0003-2809-6211

Academia.edu: https:/ / pusc.academia.edu/JorgeMilánFitera

E-mail: milan@pusc.it.

\section{How to cite}

Sierra-Sánchez, J., Abuín Vences, N. and Milán Fitera, J. (2021). 'The coronavirus pandemic narratives in Italian digital media'. JCOM 20 (02), A07. https://doi.org/10.22323/2.20020207. 